\title{
Social capital and career planning amongst first generation and non-first generation high school and college students in Germany: a social network analysis approach
}

\author{
Britta Wittner $^{1}$ (D) Simone Kauffeld ${ }^{1}$
}

Received: 2 November 2019 / Accepted: 31 October 2021

(c) The Author(s) 2021

\begin{abstract}
An important factor for First Generation High School students (FGS) in higher education is social capital. To highlight differences in social capital between FGS and their Non-FGS peers (NFGS) by analysing the structure of their ego-centred social networks and its' effect on their career planning, we conducted two crosssectional studies: on high school students during their first career planning stage and on college students at the beginning of their first semester. FGS have significantly less social capital in their networks than NFGS during school and university. Having academic supporters is associated with career planning amongst high school students, having instrumental support for career planning amongst college students.
\end{abstract}

Keywords First generation students $\cdot$ Social capital $\cdot$ Career planning

\section{Résumé}

Le capital social et la planification de carrière parmi des lycéens et universitaires de première génération ainsi que d'autres générations d'Allemagne - Une approche d'analyse des réseaux sociaux Un facteur important pour les étudiants de première génération (FGS) dans l'enseignement supérieur est le capital social. Pour mettre en évidence les différences de capital social entre les étudiants de première génération (FGS) et leurs pairs d'autres générations (NFGS) en analysant la structure de leurs réseaux sociaux centrés sur l'ego et son effet sur leur planification de carrière, nous avons mené deux études transversales: sur des lycéens pendant leur première phase de planification de carrière et sur des étudiants universitaires au début de leur premier semestre. Les étudiants de première génération (FGS) ont significativement moins de capital social dans leurs réseaux que ceux d'autres générations

Britta Wittner

b.wittner@tu-braunschweig.de

Simone Kauffeld

s.kauffeld@tu-braunschweig.de

1 Department of Industrial/Organizational and Social Psychology, Institute of Psychology, Technische Universität Braunschweig, Spielmannstraße 19, 38106 Brunswick, Germany 
(NFGS) pendant la scolarité et l'université. Le fait d'avoir des soutiens académiques est associé à la planification de carrière chez les lycéens et le fait d'avoir un soutien instrumental à la planification de carrière chez les étudiants.

\section{Zusammenfassung}

Soziales Kapital und Karriereplanung-Soziale Netzwerkanalyse der egozentrierten Netzwerke von deutschen First-Generation Studierenden vor und nach dem Übergang an die Hochschule Soziales Kapital ist ein wichtiger Erfolgsfaktor für First-Generation Studierende (FGS) an Hochschulen. Um die Unterschiede im sozialen Kapital zwischen FGS und nicht-FGS (NFGS) zu beleuchten, werden die Strukturen ihrer egozentrierten Sozialen Netzwerke sowie der Zusammenhang zu ihrer Karriereplanung analysiert. Die Ergebnisse zweier Querschnittsstudien (je mit Oberstufenschülerinnen und Erstsemesterstudierenden) zeigen, dass FGS über signifikant geringeres soziales Kapital in ihren Netzwerken verfügen und dieses nutzen können. In der Schule sind unterstützenden Akademiker*innen wichtig für die Karriereplanung, während zu Beginn des Studiums instrumentelle Unterstützung benötigt wird.

\section{Resumen}

Capital social y planificación de la carrera entre estudiantes de educación secundaria y estudiantes universitarios de primera generación y de no primera generación en Alemania - un enfoque desde el análisis de redes sociales Un factor importante para los estudiantes de primera generación (PGS) en la educación superior es el capital social. Con el fin de resaltar las diferencias en el capital social entre PGS y sus pares no PGS (NPGS) mediante el análisis de la estructura de sus redes sociales centradas en el yo y sus efectos en la planificación de su carrera, realizamos dos estudios transversales: en estudiantes de educación secundaria durante su primera etapa de planificación de carrera y en estudiantes universitarios al comienzo de su primer semestre. Los estudiantes PGS tienen significativamente menos capital social en sus redes que NPGS durante el instituto y la universidad. Tener partidarios académicos está asociado con la planificación de la carrera entre los estudiantes de educación secundaria, y también con tener un apoyo fundamental para la planificación de la carrera entre los estudiantes universitarios.

\section{Introduction}

In modern society, achieving a higher education than your parents seems to be a more desirable goal than ever. For many students, being the first in the family to start a tertiary education is not an easy path. While only $37 \%$ of First Generation High School students (FGHS) in Germany who hold a degree that enables them to start at universities (German secondary school leaving examination Abitur) decide to take up courses (Middendorf et al., 2012), 80\% of students with an academic family background (Not First Generation Students, NFGS) - students whose mothers, fathers or both hold university degrees-get a college education. In an attempt at 
social advancement, FGS tend to choose more practical majors (business studies, teaching degrees) than their peers, which promise more financial security (Kojaku et al., 1998). Although FGS account for $50 \%$ of the total student population in Germany, they are a group at high risk of dropping out of their studies early. One in five leaves, the university or at least their field of study (Ishitani, 2006; Middendorf et al., 2012). This might be because an individual's education and status is still dependent on their intergenerational background and this does not only include the parental generation but might go back as far as one's great grandparents (Braun \& Stuhler, 2018). An explanation could be that individuals often inherit their families' social class and therefore start with different amounts of social capital, meaning the people you get to know and the support you thereby receive (Bourdieu, 1987).

Pascarella et al. (2004) group FGS research into three general topics: (1) comparison studies of FGS versus academic offspring, (2) the transition phase from schools to college or university and (3) the university experience of FGS, e.g. college life and retention (Pascarella et al., 2004). In all three research topics, FGS seem to have more difficulties than their peers. To analyse what kind of social capital is important for FGS and NFGS, we conducted two studies incorporating all three topics. Considering that students will likely lose memberships to some former communities and will build new relationships to adapt to university during their transition (Tinto, 1975, 1987; Elkins et al., 2000) we opted for two studies: one before and one after transition to university. In study one, we focus on first generation and non-first generation high school students (FGHS and NFGHS) in a pre-transition stage close to their matriculation examination (German Abitur). Study two analyses college students in an early post-transition stage shortly after deciding on a tertiary education. In both studies, we also provide evidence on how different social capital is linked to career planning for both FGS and NFGS.

Whilst individuals face ongoing career decisions over their lifetime, the first career decision is tough and seems to be life-defining for high school students. Career planning, as the ability to deliberate future careers and goals and planning steps to reach them (Gould, 1979), is influential in these decisions. Being able to choose between 327 non-academic vocational educations (Bundesinstitut für Berufsbildung, 2018) and over 8000 bachelor degree programmes in Germany alone (Hochschulrektorenkonferenz, 2016), most high school students seek support for career planning which is often found in the individual's closest social circle. Therefore, we chose a social network analyses (SNA) procedure to see where college and high school students gain their social capital from. Precisely, we analyse the supporters in participants networks, which we explain in detail later on. Most studies analyse the support students retrieve from their parents or the social support the students feel they get (e.g., Levine \& Nidiffer, 1996). By having FGS include their whole support system and not only their parents or teachers, we gain insights into the support they have access to and how effectively they use the network. In a fairly new approach, we combine this SNA data with the psychometric dependent variable career planning ability.

With this study, we contribute to a deeper understanding of social capital manifestation in FGS social networks as an antecedent for career planning and add to the research on FGS in all three key topics (Thomas \& Quinn, 2007), answering 
the questions of whether they have less social capital in their social networks and whether this social capital is important for their career planning. This helps to establish suitable steps for helping FGS on their academic and occupational path. We do so by giving a theoretical introduction to social capital as well as career planning and highlight the role of FGS status in both concepts. The results are discussed with regards to improving the situation for FGS.

\section{Social capital as the key to success}

Social capital is a widely used construct in social sciences as well as psychology but lacks a clear unifying definition. Attempts vary from a structural definition (Burt, 2000) to one based on actors "bonding and bridging" (Putnam, 2000; for an overview see Claridge, 2004). In general, social capital refers to the social and relationship resources an individual and all actors can access to achieve certain goals they would not have reached alone (Coleman, 1988). According to Bourdieu (1986), social capital means the totality of real or potential resources from membership in a group. Its power is measured in the "material or symbolic profits" gained from the relationships and the form of capital associated with membership (i.e. economic, cultural, or symbolic capital) in a certain class (Bourdieu, 1987). The access to these "more or less institutionalized relationships of mutual acquaintance and recognition" (Bourdieu \& Wacquant, 1992, p. 119) is restricted by various constraints, such as race, gender and class. According to this definition, FGS are likely to have less social capital with regards to university than their fellow students, since they were neither born into an academic network nor belong to the group themselves yet.

Approaches to social capital analysis differ in accordance with its definition, from single-item measures (mostly in sociology) to psychometrical scales (Schulz \& Schwarzer, 2003) to social network analysis. We chose the last approach and provide an overview in the next paragraphs.

\section{Social capital in social networks}

Social capital in social network analyses refers to contacts (called alters in social network analysis) that help an individual (called ego in social network analysis) to use their human capital (knowledge, competencies) (Burt, 1992). Being in such a network enables all actors to gain benefits by their social structures (Portes, 1993).

Social capital has been defined widely during the last few decades. Early operationalisations mainly focused on the sheer size of the network and the power of the people in it (Bourdieu, 1986) or on social network structure. According to Burt (1992), social capital materializes in networks in four ways: size of network, heterogeneity, compositional quality and density. Network size means the sum of people an ego names as the ones supporting him or her. The size can also vary due to the form of support: social emotional (e.g. companionship), instrumental (supportive actions), informational (giving information), appraisal (e.g. feedback; House, 1981). With regards to the research questions, all support forms-emotional support, instrumental support for academic achievements and instrumental career support-can be 
counted in one general support network or they could be analysed individually. Heterogenity is a way of explaining how people in the network differ from each other and ego on certain aspects (e.g. gender, age...). High heterogeneity is supposedly beneficial for social capital as a diverse network offers a broader range of ideas and resources; that is, if it does not conflict with compositional quality. Compositional quality means the sum of alters with high levels of necessary resources such as knowledge and power. While these structures are beneficial to social capital, density is controversial. Density is the proportion of alters that have a relationship with each other or at least know each other. In favour of cohesion, it is an indicator of close relationships and beneficial (Crossley, 2005). On the other hand, it could possibly harm an individual's social capital. In a highly dense network, all alters know each other and the same things, which could lead to group think and uniform influences (Granovetter, 1973).

FGS are faced with a lack of economic as well as social capital (Soares, 2007). They gain less information from their parents directly, even though parents try to be supportive and are often more proud than other parents. In addition, they often report feeling less supported by tutors and teachers compared to NFGS, although they might be in their network (Stanton-Salazar, 2001). Once at university, FGS seldomly feel they can approach staff and faculty with their problems (Jenkins et al., 2013; Pike \& Kuh, 2005). Social capital from other contexts might be limited by social class, since individuals tend to form relationships with people similar to them (homophily; Granovetter, 1983).

\section{Social capital theory: combining accessibility and mobilisation of contacts}

Acknowledging that social capital is more than relationships and networks (Lin, 1999), Lin (2001) combines a variety of SNA approaches in his social capital theory (Figure 1).

According to the theory, social inequality depicts the access to network resources (accessibility) and contact resources (mobilization). Whereas network resources are all possible resources in the ego-centred network, contact resources refer to used resources that lie in the contacts' characteristics (knowledge, power). Naturally, accessibility influences mobilisation, whilst both lead to instrumental returns (e.g. university success) and expressive returns (e.g. satisfaction). FGS face inequalities during their school and university experience (Rubio et al., 2008) and they have potentially less access to a network helpful for facing career decisions and cannot mobilise it as well as NFGS (Engle \& Tinto, 2008). FGS are often assumed to have lower social capital (Moschetti \& Hudley, 2015). Being the first in their family to study, they have a hard time accessing a helpful network. Most adolescents' networks are influenced by their parents (Mounts, 2000). Due to the same environment, they share many contacts by chance as well as by introducing them to influential people. Furthermore, relationships often develop due to homophily (shared interests or characteristics). This influences students' and parents' networks alike. Since social capital can be contextual, we concentrate on support networks with regards to school, university and career related factors. FGS are often raised in low-income 
areas with citizens having low social capital (American Psychological Association, 2013) and often shy away from asking teachers for help (Terenzini et al., 1996). Less educated environments could lead to smaller support networks in educational matters, whilst getting to know fewer academics. The purpose of our studies is to analyse the social networks of FGS for the social capital they hold and its effect on students' career planning. We assume that FGS have significantly (a) smaller networks and (b) fewer academic alters than NFGS (H1).

Understandably, one can only mobilise contacts they have in a network. While all forms of support are important for successful careers (Dobrow \& Higgins, 2005), mobilising supporters for a specific task can be more difficult. Concerning career planning, instrumental support matching the task is more important than social emotional support (Zikic \& Klehe, 2006). In order to represent the contextual importance of instrumental support, we analysed supporters that were specifically used for support for career decision-making. We expect to find that compared to NFGS, FGS have significantly (a) fewer alters to provide them with instrumental support for vocational decision-making and (b) fewer academic alters providing them with instrumental support for vocational decision-making $(\mathrm{H} 2)$.

\section{First vocational choice and career planning: what capital do you need?}

High school and college students face a variety of simultaneous developmental processes to becoming adults (Jordan \& Kauffeld, 2018). Nonetheless, the importance of career planning increases in late adolescents (Super, 1990), as it is the basis for the complete path of ones' career and shown to be related to career satisfaction (Aryee \& Debrah, 1993) and career success (Hall, 2002). Career planning is an ongoing process through all stages in life (Zikic \& Klehe, 2006) and since the final direction is not clear yet, career planning is still very important during the first years at university (Jordan \& Kauffeld, 2018). This is especially true in the German tertiary education system. Students must decide on a major before enrolling at a university and not only apply to a university but also for their field of study (bachelor's programme). They cannot start university without a declared major, and changing majors is not as easy as in other higher education systems (e.g. the USA). For example, high school students could choose to apply to major in engineering. Starting at university, they lay a wider basis for the coming career but need to narrow it down further to a specific field in engineering or a certain industry.

The first vocational choice is often based on own motives, values and interests (Super, 1990). However, career planning not only depends on the individual's abilities (human capital) but also on the opportunities and information social capital provides (Friesen, 2011). In the context of careers research in adulthood, so-called developmental networks are key. In these networks, all actors support an individual in their career-oriented development by providing mostly professional support (Higgins \& Kram, 2001). Mentoring, a dyadic approach to building support networks, shows to improve students' career planning (Renn et al., 2014). Using the developmental network approach on students' career planning takes into account how career goal setting as well as planning is often influenced by social context (Lent 
et al., 2000) and that students have more than one support person to help them with their career. Especially for Goulds approach of career planning a developmental network is helpful. Supporters may help with the deliberation of future careers and give important insights. They can help formulate realistic goals and (as experienced in the professional world) can help planning the steps to reach these career goals. In terms of career decisions, both close and loose contacts can be beneficial. Strong relationships, such as family, can provide help in difficult transitions, whilst weak relationships have a high probability of offering fast new information (Barthauer \& Kauffeld, 2018). According to Granovetter (1979) having a widespread network provides the individual with diverse information on jobs and job opportunities. Nevertheless, adolescents tend to search for support and often use more available contacts instead of supporters they assess as most helpful (Taviera et al., 1998).

According to social capital theory (Lin, 2001), accessibility and mobilisation is an important success factor for both advantaged (NFGS) and disadvantaged (FGS) groups. While the first career decisions are difficult, career planning does not stop after choosing an academic field.

Therefore, we assume in both studies that career planning can be significantly predicted by accessibility of social capital [(a) network size, (b) number of academic alters] and mobilisation of social capital [(c) degree of instrumental support, (d) degree of instrumental support by academic alters] (H3).

To represent individuals during their first career decision in school as well as the first steps at university, we conducted two cross-sectional studies from a high school students' panel and a university freshmen panel.

\section{Study 1: Social capital and high school students' career planning}

\section{Method}

\section{Participants}

The study sample consists of 90 high school students in senior classes (68\% year 11, $27.5 \%$ year 12 and $2.2 \%$ in year 13 , which is the last year in certain school forms) from the same city. We chose schools from the same city to control for regional effects of the educational federalism in the German school system (in Germany education is decided in each federal government, respectively). Participants were on average 16.9 years old $(S D=.81)$. Girls made up $65.9 \%$ whilst $33 \%$ were boys. On average, 90 participants named 5.97 alters $(S D=3.47)$ in their ego-networks. On average, $1.97(S D=2.23)$ alters per network offered vocational support. Seventeen percent of all alters had a tertiary degree and were therefore presumed to be academics. One third of the high school students in the sample self-identified as FGS $(n=30)$. As there are various definitions of the term FGS, Toutkoushian et al. (2018) request researchers to describe their measure in detail. While all measures of FGS have the same tendency in their results, we decided on a perceptual approach, to include a variety of concepts on nuclear family and university experiences. Therefore, in this study, being the first in the family to study was measured as their social 
identity (Tajfel et al., 1979) by a single item to measure their perceived status as such ("Are you the first in your family to study at a University?" or "Would you be the first in your family to study at a University?" for the high school sample). With an average score of career planning of $M=3.37(S D=1.19)$ for FGS and $M=3.42$ $(S D=1.07)$ for NFGS career planning levels were low in both groups.

\section{Instruments}

Career planning Career planning was measured by a German translation of Gould's (1979) career planning scale (Rowold, 2004). Commonly used in various studies (Thomas et al., 2007), the scale is related to salary, adaptability (Gould, 1979) and following a carer strategically (Aryee \& Debrah, 1993).

The scale consists of 9 items on a 6-point scale from 1 (not at all) to 6 (completely) with two subscales (career adaptability and career planning). Sample items are: "I have a plan for my career" and "I know what I have to do to fulfil my career goals". Cronbach's alpha coefficients in this study were good, with $\alpha=.86$ for the first study and $\alpha=.80$ for the second study.

Developmental network questionnaire Participants were asked to list up to 20 alters (e.g. friends from school, parents, teachers) that support them in their career development in a so called name generator. As name generator, we asked participants for people who supported them with regards to school, university and career related factors during the last six months and provided example behaviours of possible supporters (e.g. providing information or creating career opportunities) to facilitate the name gathering for the participants (adaptation from Dobrow \& Higgins, 2005). The number if alters they decided to list is the network size.

Next, participants were presented with a set of questions for each alter they mentioned as a member of their social network (e.g. relationship_-are they family, friends, friends from university; age; academic degree reaching from no degree to habilitation treatise) and were able to decide which support form alters were offering them: socio-emotional support and instrumental support for vocational decisionmaking and university. To help participants rank the support forms, we gave definitions at the beginning of the questionnaire. Participants were able to check as many forms of support they gained from an alter as they felt applied.

We counted alters as academic if they had atleast a bachelor's degree and used the support form as reported by the participants.

\section{Procedure}

In the two studies we used paper pencil surveys with psychometrical scales (career planning ability) as well as social network questionnaires. Samples in study one and study two consist of both FGS and NFG students. The unit of analysis is the ego and the network of each participant. The description of the alters provides further insights into the composition of the participants' networks. 
In study one, we chose to focus on high school students' social capital since we assume it to be influential on their first career planning steps and in leading them on towards successful (academic) careers. The data were gathered in high schools offering their students a programme in which they can choose to participate in a career coaching. All of the participants applied for a career decision-making programme in schools in lower Saxony. Some of them got the treatment right after the survey whilst others had to wait six months for the coaching. All of them got our survey before the programme started.

\section{Data preparation: social support measures in networks}

We measured social capital according to Burt $(1992,2000)$ whilst applying Lin's Model of social capital. We used network size (also referred to as degree) and compositional quality (Burt, 1992) as measures for students' social capital accessibility (Lin, 2001).

Degree /network size is the sum of all alters in an ego network. Since all contacts were valuable for ego, we did not filter for specific support.

Support is often referred to a specific context. Compositional quality argues that social capital is also measured by the support an ego gains for a specific cause. According to Burt (2000), we measured the alters' possessing of characteristics valuable to ego. In this case, we used their academic background.

Furthermore, we measured mobilised social capital (Lin, 2001) by alters used for instrumental support for career decision-making as well as by combining the academic background of alters with this specific instrumental support. We assumed academic help to be mobilised if alters with academic background gave instrumental support instead of general support.

\section{Controls}

We controlled for age and gender. While both are an influencing factor for network parameters (Barthauer et al., 2016; Vaux, 1985), age can also affect career maturity (Creed et al., 2007). As explained above, participants applied for a career decisionmaking programme. Though all participants had not received any information at or before measurement and attended the same schools and classes, participating in the programme was used as a control variable, since Jordan et al. (2017) found an effect in a similar programme.

\section{Data analyses}

To test our hypotheses, we used SPSS 25. To reduce possible multicollinearity, predictors were mean centred before conducting the regression analyses (Aiken \& West, 1991). We first ran the tests on our hypotheses 2 and 3 for the whole sample in both studies. To establish whether against our assumption that they might only apply to FGS, we calculated the same regression analyses for FGS only. 
Table 1 Means and Standard Deviation of all relevant variables for both FGS and NFGS in study 1

\begin{tabular}{|c|c|c|c|c|c|c|c|}
\hline & \multicolumn{2}{|l|}{ FGS } & \multicolumn{2}{|c|}{ NFGS } & \multirow[t]{2}{*}{$t$} & \multirow[t]{2}{*}{$p$} & \multirow[t]{2}{*}{ Cohen's $d$} \\
\hline & $M$ & $S D$ & $M$ & $S D$ & & & \\
\hline Network size & 5.45 & 4.23 & 6.21 & 3.02 & -.87 & .14 & \\
\hline Sum acad. Alters & .76 & 1.09 & 1.24 & 1.44 & -1.78 & .04 & .38 \\
\hline Instrumental Support & .31 & .54 & .98 & 1.40 & -.573 & $<.001$ & .63 \\
\hline Acad. Instrumental support & .48 & .82 & .93 & 1.28 & -1.78 & .04 & .42 \\
\hline
\end{tabular}

Table 2 Study 1 Bivariate Correlations amongst assessed constructs

\begin{tabular}{lccccccccc}
\hline Variable & $\mathrm{M}$ & $\mathrm{SD}$ & 2 & 3 & 4 & 5 & 6 & 7 & 8 \\
\hline 1 Treatment & & & $.26^{* *}$ & .03 & $-.27^{* *}$ & .10 & -.16 & .12 & $.35^{* *}$ \\
2 Age & 16.89 & .81 & & .16 & $-.27^{* *}$ & -.11 & $-.30^{* *}$ & $-.23^{*}$ & .05 \\
3 Gender & & & & & $-.20^{*}$ & -.01 & $-.19^{*}$ & -.12 & .13 \\
4 Sum Alters & 5.97 & 5.97 & & & & $.41^{* * *}$ & $.78^{* * *}$ & $.40^{* * *}$ & .05 \\
5 Sum Academic Alters & 1.07 & 1.35 & & & & $.43^{* * *}$ & $.88^{* * *}$ & $.23^{*}$ \\
6 Instrumental support & 1.96 & 2.23 & & & & & $.50^{* * *}$ & $.26^{*}$ \\
7 Academic Instrumental Sup- & .67 & 1.18 & & & & & & .11 \\
$\quad$ port & & & & & & & & & \\
8 Career Planning & 3.62 & .84 & & & & & & \\
\hline
\end{tabular}

$N=90 ; M$ and $S D$ are given

$* p<.05, * * p<.01, * * * p<.001$

\section{Results study 1}

For hypothesis one, we conducted four one-tailed independent sample t-tests to compare (1) network size, (2) sum of academic alters and (3) instrumental support and (4) instrumental support by academic alters in FGS and NFGS conditions. We used one-sided tests since we assume a directional effect. There was no significant difference in network size for FGS $(M=5.45, S D=4.23)$ and NFGS $(M=6.21, S D=3.02) ; t(42)=-.87, p=.14$. There was a significant difference in academic alters for FGS $(M=.76, S D=1.09)$, who reported significantly less academics than NFGS $(M=1.24, S D=1.44) ; t(71)=-1.78, p=.04, d=.38$. Again, there was also a significant difference in instrumental support for FGS $(M=.31$, $S D=.54)$ and NFGS $(M=.98, S D=1.40) ; t(81)=-.573, p<.001, d=.63$, and they significantly differed in instrumental support by academics $t(71)=-1.78$, $p=.04, d=.42\left(M_{F G S}=.48, S D_{F G S}=.82 ; M_{N F G S}=.93, S D_{N F G S}=1.28\right)($ Tables 1, 2).

All variables' correlations can be found in table two. In contrast to our hypothesis $\mathrm{H} 3$, only sum of academic alters and instrumental support correlated significantly with career planning - to comprise this, we decided to test our regression model with these variables only. Interestingly, no correlations were significant for NFGHS alone. 
The model using instrumental support explained a share of $R^{2}=.14$ (adjusted $R^{2}=.123$ ) of the variance, indicative for a moderate goodness-of-fit according to Cohen (1988). The amount of academic support significantly predicted career planning $(\beta=.24, p=.024), F(2,81)=6.82, p=.002$, whilst instrumental support was excluded due to insignificance $(\beta=.15, p=.31)$ in a step-wise regression.

\section{Discussion study 1}

In conclusion, network size was not significantly different for NFGS and FGS. Nonetheless, FGS did have significantly less academics in their network report and less instrumental support, and received less academic instrumental support. While testing our regression model, we found a significant relationship between academic alters in the network and career planning for all students. This is especially concerning, due to the lack of academics in FGS networks. While $12 \%$ of explained variance might seem small, there are various factors influencing career planning and academic alters seem to add up to the positive influence on career planning.

While we found this in a sample of high school students, research shows how social networks and therefore social capital changes in times of transition (Brissette et al., 2002). To observe how social capital and its relationship to career planning changes at university, we conducted a second study using first semester university students.

\section{Study 2: Social capital and university students' career planning}

\section{Method}

\section{Sample}

The study's sample consists of 123 students at the beginning of their first semester at the same university. We chose to use one university to control for context factors of different curriculars such as mandatory mentoring, networking trainings and career counselling. The particular university offers a diverse range of fields, reaching from STEM to social sciences. Participants were on average 19.86 years old $(S D=2.56)$. Seventy-three percent were women and $27 \%$ were men. In total, 123 participants named 1058 alters, on average 8.60 alters $(S D=3.84)$ per ego network. $M=2.93$ $(S D=2.72)$ alters per network were giving the participants instrumental support for university and career. Twenty-three percent had a tertiary degree and were therefore presumed to be academics. Nearly half of the students in the sample self-identified as FGS $(n=57)$. With an average score of career planning of $M=4.16(S D=.92)$ for FGS and $M=4.23(S D=.74)$ for NFGS career planning levels were low in both groups but higher than in the high school sample. 


\section{Instruments}

We used the exact same instruments on the second sample. To adapt the social network questionnaire to university life we added the category "friends from university". Since there was no treatment and control groups, we did not control for group effects but kept age as control variable.

\section{Procedure}

In the second study, we also used paper pencil surveys with psychometric scales (career planning ability) as well as social network questionnaires. Again, the sample consisted of both FGS and NFGS. Surveys were conducted in seminars at the beginning of their first semester. The unit of analysis is the ego and the network of each participant. The description of the alters provides further insights into the composition of the participants' networks.

\section{Results study 2}

For hypothesis one, we conducted four one-tailed independent sample t-tests to compare (1) network size, (2) sum of academic alters and (3) instrumental support and (4) instrumental support by academic alters in FGS and NFGS conditions. There was a significant difference in network size for FGS $(M=7.23, S D=2.96)$ and NFGS $(M=9.788, S D=4.12) ; t(117,23)=-3.992, p<.001, d=.73$, and instrumental supporters for FGS $(M=3.16, S D=2.90)$ and NFGS $(M=4.48$, $S D=2.92) ; t(121)=-2.52, p=.013, d=.45$. FGS had significantly less academic alters in their network $(M=1.02, S D=1.26)$ than NFGS $(M=2.08, S D=1.92) ; t$ $(113,41)=-3.66, p<.001, d=.65$. Accordingly, we found a significant difference in instrumental support from academics for FGS $(M=.57, S D=.91)$ and NFGS $(M=1.18, S D=1.40) ; t(112,81)=-2.889, p=.005, d=.52$.

Since the predictor variables sum of academic alters (H3) and Academic Instrumental Support $(\mathrm{H} 4)$ correlations with career planning did not gain significance (see Table 4 for all correlations), we resolved to test our regression model without these variables. Looking at the correlations for FGCS and NFGCS separately we found, that none of the parameters have a significant relationship with career planning. We included instrumental support and network size into a step-wise regression (Tables 3, 4).

The model did not gain significance for the whole sample $F(2,63)=2.01, p=.14$. We tested the model for both network size and instrumental support at the same step and found that network size did not gain significance. Age (control variable) and instrumental support were able to predict career planning, $F(2,54)=6.484, p=.003$. Nineteen percent of variance could be explained by age and instrumental support (adjusted $R^{2}=.16$ ), indicative of a moderate goodness-of-fit according to Cohen (1988). 
Table 3 Means and Standard Deviation of all relevant variables for both FGS and NFGS in study 2

\begin{tabular}{|c|c|c|c|c|c|c|c|}
\hline & \multicolumn{2}{|l|}{ FGS } & \multicolumn{2}{|l|}{ NFGS } & \multirow[t]{2}{*}{$t$} & \multirow[t]{2}{*}{$p$} & \multirow[t]{2}{*}{ Cohen's $d$} \\
\hline & $M$ & $S D$ & $M$ & $S D$ & & & \\
\hline Network size & 7.23 & 2.96 & 9.788 & 4.12 & -.87 & $<.001$ & .73 \\
\hline Sum acad. Alters & 1.02 & 1.26 & 2.08 & 1.92 & -3.66 & $<.001$ & .65 \\
\hline Instrumental Support & 3.16 & 2.9 & 4.48 & 2.92 & -2.52 & .013 & .45 \\
\hline Acad. Instrumental support & .57 & .91 & 1.18 & 1.4 & -2.89 & .005 & .52 \\
\hline
\end{tabular}

Table 4 Study 2: Bivariate Correlations amongst assessed constructs

\begin{tabular}{llllllllll}
\hline Variable & $\mathrm{M}$ & $\mathrm{SD}$ & 1 & 2 & 3 & 4 & 5 & 6 & 7 \\
\hline 1 Age & 19.44 & 2.21 & -.10 & .02 & .08 & -.00 & .20 & $.35^{*}$ \\
2 Gender & & & & -.07 & -.16 & -.10 & -.06 & -.12 \\
3 Sum Alters & 7.43 & 3.15 & & & $.372^{* * *}$ & $.723^{* * *}$ & $.29^{*}$ & .19 \\
4 Sum Academic Alters & 1.67 & .20 & & & & .19 & $.58^{* * *}$ & .27 \\
5 Instrumental support & .295 & 2.72 & & & & & $.35^{* * *}$ & $.31^{* *}$ \\
6 Academic Instrumental Support & .84 & .15 & & & & & & .20 \\
7 Career Planning & 4.4 & .17 & & & & & & \\
\hline
\end{tabular}

$N=90 ; M$ and $S D$ are given

$* p<.05, * * p<.01, * * * p<.001$

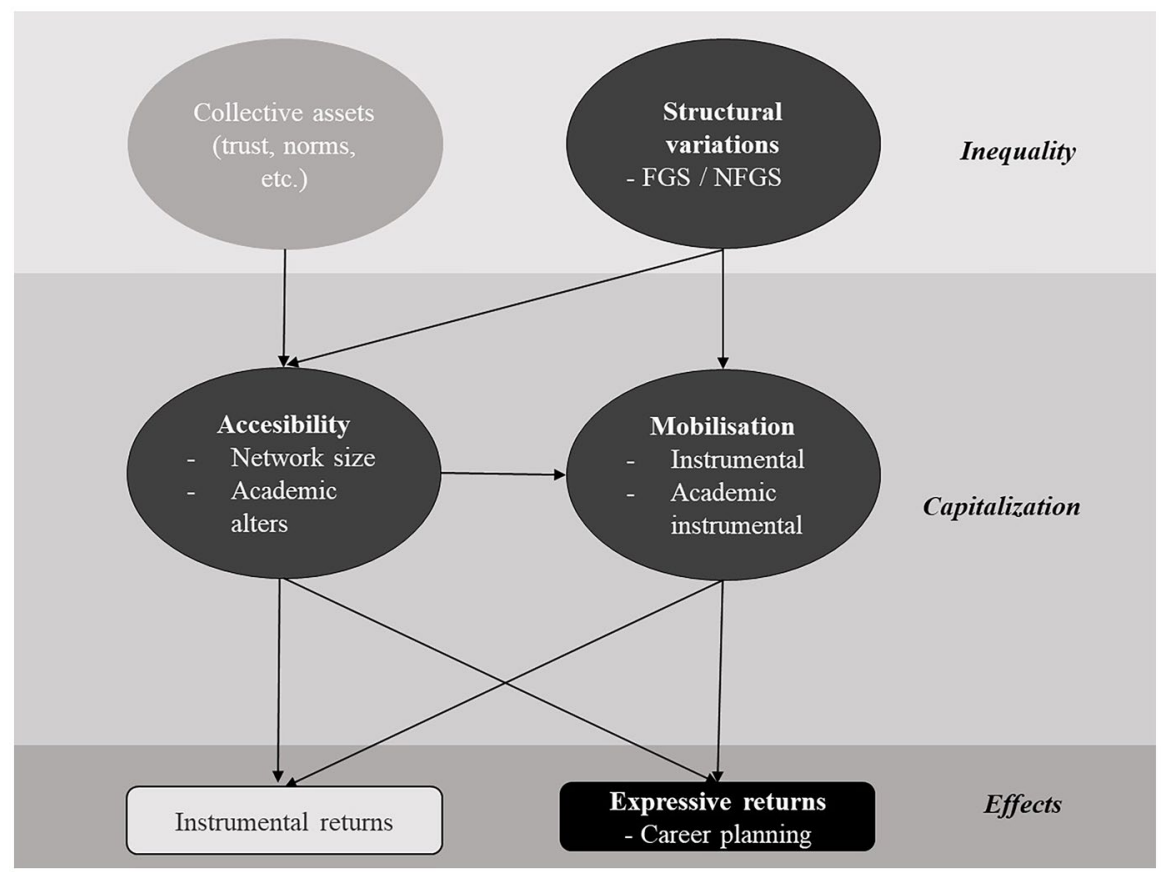

Figure 1 Model based on Lin's Social Capital Theory (2001)—analysed factors are in darker shades 


\section{Discussion study 2}

We did find significant differences in all social capital variables: network size, academics alters, instrumental support and instrumental support by academics with small to medium effect sizes. To our surprise, none of the variables were predictive for the whole sample-looking closer, we did find a fitting model for FGS only. In FGS students, there is a significant relationship between instrumental support and students' career planning.

\section{Study 3: Case studies on FGS and NFGS}

To follow up on the sample of study 2, we conducted a third study and led interviews with two of the participants in study 2 at the end of their bachelor's degree. All participants were contacted via mail and the two participants were chosen since they were very representative for their group.

\section{Method}

\section{Participants}

Both participants were at the end of their bachelor's degree in the same major. FGCS is 21 years old, NFGCS started his university career later and is 26 . Both are in the fifth semester and started their studies at the same time.

\section{Data collection}

The semi-structured interviews were conducted by the same experienced and specifically trained interviewer to avoid interviewer bias. Participants were not familiar with the interviewer and all interviews took place in the same environment. The interviews were approximately $60 \mathrm{~min}$ long and followed the same script, respectively. Both interviews were recorded and basically transcripted.

The interview script combined an approach by Herz et al. (2015) and consisted of the (a) participants demographics, (b) questions concerning their SES, (c) their understanding of different support forms (emotional and instrumental support) and (b) their social networks (name generator and deeper questions on the alters as well as alter-alter relations). The name generator was an adaptation of Burt's (1984) and asked for the most important support persons in the participants lives during their bachelor's degree. While participants were able to name all supporters, detailed questions concerning the actual support they perceived were only asked for the five most important. We decided on this approach, since reports are more indepth and data quality is higher for alters of the Kernnetzwerk (Kogovšek et al., 2002). We asked for all alters, how supported they felt by their network, whether they wished they had more support and how heterogenous they perceived their network to be. 
To see how sure they were about their career decisions, we asked what degree they wanted to achieve and which job they are aiming for.

\section{Data analysis}

All Interviews were coded by a trained coder using qualitative content analysis, in order to compare the networks of both participants. We used deductive categories based on study one and two as well as the current state of empirical results.

\section{Results}

Both participants reported 13 alters in their respective networks. FGCS and NGCS both feel highly supported by their network and when first asked, decline the need for any additional support. Nonetheless, we found references for the differences in social capital between FGS and NFGS. Both report mostly alters that went to university - the difference being, that NFGCS knew most of these academics before starting university themselves, whereas FGCS reports academics that study with her or are in also stoll in their bachelor's degree in a different major. This shows that she got to know these alters by pursuing a degree herself, whereas NFGCS had academic alters before starting his bachelor's degree.

For the NFGCS, the most important contacts (five alters he chose to give more information on) were the emotional close contacts, whilst the FGCS also chose less close contacts as well. Following the notion of Granovetter (1973), these so-called weak ties could provide valuable social capital and be beneficial for a future career (Granovetter, 1973).

Both participants report that they do not perceive a difference between FGCS and NFGCS in everyday college life. Without naming it a difference, the FGCS later explains that "other students got instrumental support placed in the cradle", since they benefit off their parent's professional relationships, e.g. for internships. She later describes that she did wish for more instrumental support during her bachelor's but "managed to do it without". This difference in support could thus be a blind-spot for the students themselves and explain differences in self-reported social support and the social capital in their networks. She also describes a "safety" she perceives in both her parents and their trust, that she can achieve anything, if she wants to. This shows, that emotional support is not necessarily the support FGCS are lacking.

On the flipside, the FGCS network provides her with something the NFGCS does not have: a very heterogeneous network that provides her with different influences (cultural, political, religious) and allows her to "see things from a different perspective" and widens her view and therefore her options, interests and outlook on life.

We found evidence for the empirical results concerning career planning in study 1 and 2 in both interviews. NFGCS did not remember being influenced by his network in his career planning, choice for a bachelor's degree and his current dream job. Nonetheless, he has a more set idea of his professional life than FGCS who is indecisive between two very different fields "or something else entirely. Who knows?". FGCS feels a lack of vocational instrumental support, which might lead 
to more job opportunities, since she does not have contacts in her envisioned fields. Her decision for psychology was strengthened by a role-model during her time in high school, who was a psychologist and gave her insights into the field as well as the self-efficacy she needed to apply. Thus, the interviews show the importance of academic alters for FGS during school and instrumental support whilst at university—whilst the NFGS would not report these needs.

\section{General discussion}

In the present studies, we aimed to establish whether FGS have less social capital available in their social networks than NFGS. Furthermore, we wanted to know if this social capital is directly beneficial for FGS and NFGS career planning during school and university. To achieve this, we used a new approach, combining social network analysis and psychometric scales such as career planning in a model to distinguish accessible and mobilised social capital. In the first step, we compared FGS and NFGS social networks regarding their accessible and mobilised social capital. We then applied Lin's social capital theory (2001) to connect the students' social capital to career planning. To cover all key research topics on FGS, we conducted two independent studies: one using high school students shortly before their transition to university and one using data from a sample of students in their first semester at university. In alliance with Lin's social capital theory (2001), our results demonstrate that FGS dispose of less social capital in their networks than NFGS. In both studies, FGS report significantly less social capital in their social networks. They know fewer academics, receive less instrumental support in general and especially from academics. While FGCS have significantly smaller networks than their peers at the beginning of university, there was no significant difference in network size in the school sample between FGS and NFGS. Since we asked for different support forms (emotional, support for school/university and support for vocational decisionmaking), this could be explained by contextual factors of school life. High school students in Germany often stay in the same class group for a long time unless they change schools or move to another city. Typically, if a pupil stays in the same environment, they tend to know whom to ask for help and are familiar with the people around them. In the beginning, for career planning, high school students seek support that is easily available to them (Taviera et al., 1998). Conversely, high school students find help for school and emotional support available in their classroom on a daily basis and could be more likely to report numerous classmates, whilst they are not helpful for vocational decision-making. Therefore, there might be less social capital regarding vocational decision-making although they report comparable network sizes. Overall, we found that NFGS have more beneficial networks during all stages, since they own more social capital.

In alliance with Lin (2001), we found effects of academic alters in the network (FGHS) and instrumental support (FGCS) on participants' career planning in both samples. This aligns with previous research by Garriott et al. (2015), who found effects of students perceived social support on their career development and drop-out intention. We tried to use more objective measures in students' 
social networks and found, the more academic supporters high school students have access to at the end of their school career, the better the high school students' career planning. Since having academics in their network seems more important than mobilising them for instrumental support, one explanation could be that they see them as role models. Having people to look up to, pupils see different successful career paths and have more diverse insights into the future possibilities they have themselves. Being able to compare diverse career paths could assure them in their own career planning. Additionally, being aware of eligible supporters that could help them could provide enough assurance to avoid struggling with planning a career in this early stage. After starting university, support by academic alters did not show a significant relationship with career planning. We found that instrumental support is positively connected to the career planning of FGS at university. Which replicates findings from later career stages (Dobrow \& Higgins, 2005). Nonetheless, this support on vocational decisionmaking does not necessarily have to come from supporters who have already achieved an academic degree. We assume that this could be due to peer support gaining importance for FGS once they are at university (Tinto, 1975), since their next career planning step exceeds the decision to pick an academic path and field.

Since Lin's social capital theory has been mostly theoretical in educational research, we were able to strengthen the model empirically. To our knowledge, we are the first to apply this theory to the context of FGS as well as to career planning. We were able to demonstrate that pupils as well as university students did have different amounts of social capital all through two different career stages according to their family's educational background. Nonetheless, not all measured parameters of social capital were associated with career planning, and we were able to break down the direct effects. While network size and academic instrumental support are not significantly related to career planning in our samples of both pupils before or students after the transition from school to university, accessibility of academic alters is shown to be important during career planning in school and (peer)-support mobilisation during university.

These results point towards age and life-stage differences in having social capital and the need for social capital, as well as changes in social networks during early college from family to peer support (Wilcox et al., 2005). Moreover, we contribute to these findings using our social network approach to differentiate the accessibility of supporters from the actual usage of instrumental support for vocational decision-making processes. Thereby, we also increase the objectivity of the social support comparison of FGS and NFGS.

Furthermore, our research adds to earlier findings that a lack of social support leads to difficulties in adapting to university life, especially for FGS (Dennis et al., 2005).

The lack of social capital in combination with its direct relationship to career planning highlights the importance of help programmes for FGS. In addition, we were able to show that these differences start in school and, therefore, so should help programmes. 


\section{Practical implications}

Following the three research topics in the introduction, we provide practical implications on: (1) adjusting FGS social capital in comparison to NFGS social capital to achieve greater equality, (2) giving FGS pupils the support they need in the transition phase from schools to college or university and (3) increasing social capital in FGS students to improve their university experience and career planning.

Given our results that FGS show less social capital in their network, and said social capital's connection to career planning, we advise schools to build networks of academic mentors for their school. These could consist of alumni of the school as well as parents or older siblings of pupils. This way, pupils could build their own developmental network with the sole purpose of supporting them in their career needs (Barthauer \& Kauffeld, 2018). Since this might not be feasible for all schools, individuals could help themselves through programmes such as Big-Brother- or Big-Sister-Mentoring (for an overview see Raufelder \& Ittel, 2012). In these programmes, volunteers take up the role of a supportive mentor in pupils' lives. This way, they add at least one new person to the pupil's developmental network that could provide instrumental career support as a main focus. This kind of relationship is mostly uncommon outside of the US. While individuals could benefit from the weak ties (Granovetter, 1973) in their network by asking a friend or a sibling's friend that is in university or works in their chosen field for career advice, schools and counsellors should assist students in reflecting on their personal social network and raising their awareness to mobilise people they know. Furthermore, schools could implement new programmes for FGS. So far, German speaking countries (Germany, Austria, Switzerland) have often focused on gender-related mentoring programmes, giving girls role models of women in STEM fields. Thereby, girls are encouraged to follow a career they or their network did not consider or thought possible (Hutchinson, 2014). We advise that similar programmes focusing on FGS students' needs should be implemented. Since being the first in the family could be perceived as stigmatising and all students benefit from strengthened social capital, we advise that these programmes should be opened to all pupils whilst especially encouraging FGS to take part.

Though the instrumental career support at university is important, it does not necessarily have to come from academic supporters. We advise students to actively work on their network during their start at university. These ties do not have to be strong bonds but could also be weak ties such as distant acquaintances to enhance the campus experience (Pike \& Kuh, 2005). In adults' career research, developing weak ties leads to versatile and fast information and could therefore be beneficial for students as well. Meeting peers at networkers or other campus activities and parties, and sharing experiences and values could help form motives and further strengthen career planning. Universities should introduce different measures to increase peer instrumental support. While early introduction courses enable students to form new contacts at the beginning of their studies, they also increase FGS self-efficacy beliefs (Aymans \& Kauffeld, 2015). Furthermore, we strongly recommend the inclusion of mentoring programmes with trained mentors (Klauke et al., 2019; Perst et al., 2019), 
which are also beneficial for university adjustment and well-being (Ghosh \& Reio, 2013).

To conclude, our takeaway messages are: First, during school, pupils, parents and schools should work together to increase the academic influence in FGS lives, whether through personal contacts, structural programmes or by thinking of and activating contacts via friends and family. During transition, whilst the first decision is made, prospective students could start building their new network by joining social media groups at their new university, visiting university grounds or looking for shared apartments. Foremost, they should not worry too much-they will get the chance to find new support and most importantly the instrumental support when they start university. Once at university, we advise them to take part in campus activities to be held by the university, and for FGS to attend them.

\section{Limitations and future research}

We did find different important social capital parameters to relate to career planning in both study 1 and 2, which were underlined in study 3. Nevertheless, both studies work with cross-sectional and small sample sizes. Future research should, consequently, focus on ego-centred networks connected to psychometrical scales in a longitudinal panel to further explain the causal direction. Connecting social network parameters to career planning after a few months, before the next transition, after entering university and starting professional life would address the importance of social capital increasement as early as the end of school. With increased sample size models could be more complex and include more independent and control variables, such as educational achievement of participants.

Aside from connecting social network data and psychometrical scales from two time points, collecting longitudinal data on ego-centred social networks would also be a valuable addition to research. Analysing ego-centred networks over time is a rather innovative approach which would enhance our knowledge on network changes of support networks in transition phases. We did find interindividual differences between FGS and NFGS whilst in high school and during university. Working with one longitudinal study instead of two consecutive samples could highlight intraindividual changes of the networks of FGS and NFGS during transition from high school to college. Further research would benefit from a panel following high school pupils in their transition to becoming university students, to confirm our results and explain changes in social networks.

Our findings revealed differences in all social network parameters between FGS and NFGS, whilst not all had a direct impact on FGS students' career planning. In order to further shed light on the favourable effects of social capital claimed in the literature for FGS, additional direct effects on other career related factors should be analysed. Furthermore, social capital parameters that did not show a direct effect in our study (e.g. network size) should be analysed as indirect factors related to career planning and consequential outcomes such as retention, drop-out intention and career turnover intention. 
Lastly, theory is often divided between different forms of capital. While this study focussed on social capital, other studies analyse cultural capital (O'Shea, 2016) or economic capital (Redford et al., 2012), in which FGS and NFGS differ. Combining social, economic, cultural and thereby symbolic capital (Bourdieu, 1986) would lead to a comprehensive model fully reflecting different starting terms for FGS and NFGS. Constructing a coherent model would emphasise direct and indirect effects and might reveal more complex relationships.

Funding Open Access funding enabled and organized by Projekt DEAL. This work was supported by the Federal Ministry of Education and Research [Grant Number: 01JA1609].

\section{Declarations}

Ethical approval The study was approved by the ethical review board at the participating university (Number: DM-2016-06).

Open Access This article is licensed under a Creative Commons Attribution 4.0 International License, which permits use, sharing, adaptation, distribution and reproduction in any medium or format, as long as you give appropriate credit to the original author(s) and the source, provide a link to the Creative Commons licence, and indicate if changes were made. The images or other third party material in this article are included in the article's Creative Commons licence, unless indicated otherwise in a credit line to the material. If material is not included in the article's Creative Commons licence and your intended use is not permitted by statutory regulation or exceeds the permitted use, you will need to obtain permission directly from the copyright holder. To view a copy of this licence, visit http://creativecommons.org/licen ses/by/4.0/.

\section{References}

Aiken, L. S., \& West, S. G. (1991). Multiple regression: Testing and interpreting interactions. Sage Publications.

Aryee, S., \& Debrah, Y. A. (1993). A cross-cultural application of a career planning model. Journal of Organizational Behavior, 14(2), 119-127. https://doi.org/10.1002/job.4030140203

Aymans, S. C., \& Kauffeld, S. (2015). To leave or not to leave? Critical factors for university dropout among first-generation students. Zeitschrift Für Hochschulentwicklung. https://doi.org/10.3217/ zfhe-10-04/02

Barthauer, L., \& Kauffeld, S. (2018). The role of social networks for careers. Gruppe. Interaktion. Organisation. Zeitschrift Für Angewandte Organisationspsychologie (GIO), 49(1), 50-57. https://doi.org/ 10.1007/s11612-018-0401-2

Barthauer, L., Spurk, D., \& Kauffeld, S. (2016). Women's social capital in academia: A personal network analysis. International Review of Social Research, 6(4), 195-205. https://doi.org/10.1515/ irsr-2016-0022

Bourdieu, P. (1986). The forms of capital. In J. G. Richardson (Ed.), Handbook of theory and research for the sociology of education (pp. 241-258). Greenwood Press.

Bourdieu, P. (1987). Die feinen Unterschiede: Kritik der gesellschaftlichen Urteilskraft. Suhrkamp.

Bourdieu, P., \& Wacquant, L. P. D. (1992). An invitation to reflexive sociology. University of Chicago Press.

Braun, S. T., \& Stuhler, J. (2018). The transmission of inequality across multiple generations: Testing recent theories with evidence from Germany. The Economic Journal, 128(609), 576-611. https:// doi.org/10.1111/ecoj.12453 
Brissette, I., Scheier, M. F., \& Carver, C. S. (2002). The role of optimism in social network development, coping, and psychological adjustment during a life transition. Journal of Personality and Social Psychology, 82(1), 102-111. https://doi.org/10.1037/0022-3514.82.1.102

Bundesinstitut für Berufsbildung. (2018). Verzeichnis der anerkannten Ausbildungsberufe 2018. https:// www.bibb.de/dokumente/pdf/verzeichnis_anerkannter_ausbildungsberufe_2018.pdf

Burt, R. S. (1984). Network items and the general social survey. Social Networks, 293-339. https://doi. org/10.1016/0378-8733(84)90007-8

Burt, R. S. (1992). Structural holes: The social structure of competition. Harvard University Press. http:// search.ebscohost.com/login. aspx?direct $=$ trueandscope $=$ siteanddb $=$ nlebkanddb $=$ nlabkandAN= 282754

Burt, R. S. (2000). The network structure of social capital. Research in Organisational Behaviour, 22, $345-423$.

Claridge, T. (2004). Social capital and natural resource management: An important role for social capital? Unpublished Thesis, University of Queensland, Brisbane, Australia.

Cohen, J. (1988). Statistical power analysis for the behavioral sciences (2d ed.). Lawrence Erlbaum.

Coleman, J. S. (1988). Social capital in the creation of human capital. The American Journal of Sociology, 94, S95.

Creed, P. A., Patton, W., \& Prideaux, L.-A. (2007). Predicting change over time in career planning and career exploration for high school students. Journal of Adolescence, 30(3), 377-392. https://doi.org/ 10.1016/j.adolescence.2006.04.003

Crossley, N. (2005). Review article: The new social physics and the science of small world networks. The Sociological Review, 53, 351-359. https://doi.org/10.1111/j.1467-954X.2005.00518_1.x

Dennis, J. M., Phinney, J. S., \& Chuateco, L. I. (2005). The role of motivation, parental support, and peer support in the academic success of ethnic minority first-generation college students. Journal of College Student Development, 46(3), 223-236. https://doi.org/10.1353/csd.2005.0023

Dobrow, S. R., \& Higgins, M. C. (2005). Developmental networks and professional identity: A longitudinal study. Career Development International, 10(6/7), 567-583. https://doi.org/10.1108/13620 430510620629

Elkins, S. A., Braxton, J. M., \& James, G. W. (2000). Tinto's separation stage and its influence on firstsemester college student persistence. Research in Higher Education, 41(2), 251-268. https://doi.org/ 10.1023/A:1007099306216

Engle, J., \& Tinto, V. (2008). Moving beyond access: College success for low-income, first-generation students. Pell Institue for the Study of Opportunity in Higher Education.

Friesen, M. R. (2011). Immigrants' integration and career development in the professional engineering workplace in the context of social and cultural capital. Engineering Studies, 3(2), 79-100. https:// doi.org/10.1080/19378629.2011.571260

Garriott, P. O., Hudyma, A., Keene, C., \& Santiago, D. (2015). Social cognitive predictors of first- and non-first-generation college students' academic and life satisfaction. Journal of Counseling Psychology, 62(2), 253-263. https://doi.org/10.1037/cou0000066

Ghosh, R., \& Reio, T. G. J. (2013). Career benefits associated with mentoring for mentors: A meta-analysis. Journal of Vocational Behavior, 83, 106-116.

Gould, S. (1979). Characteristics of career planners in upwardly mobile occupations. The Academy of Management Journal, 22(3), 539-550. http://www.jstor.org/stable/255743

Granovetter, M. (1973). The strength of weak ties. American Journal of Sociology, 78, 1360-1380.

Granovetter, M. (1983). The strength of weak ties: A network theory revisited. Sociological Theory, 1(201), 56. https://doi.org/10.2307/202051

Hall, D. T. (2002). Careers in and out of organizations. Sage.

Herz, A., Peters, L., \& Truschkat, I. (2015). How to do qualitative strukturale Analyse? Die qualitative Interpretation von Netzwerkkarten und erzählgenerierenden Interviews. Forum Qualitative Sozialforschung, 16(1).

Higgins, M. C., \& Kram, K. E. (2001). Reconceptualizing mentoring at work: A developmental network perspective. Academy of Management Review, 26(2), 264-288. https://doi.org/10.5465/amr.2001. 4378023

Hochschulrektorenkonferenz. (2016). Statistische Daten zu Studienangeboten an Hochschulen in Deutschland-Statistiken zur Hochschulpolitik 01/2016. HRK.

House, J. (1981). Work stress and social support. Addison-Wesley. 
Hutchinson, J. (2014). Girls into STEM and Komm mach MINT': English and German approaches to support girls' STEM career-related learning. Journal of the National Institute for Career Education and Counselling (NICEC), 32, 27-34.

Ishitani, T. T. (2006). Studying attrition and degree completion behavior among first-generation college students in the United States. The Journal of Higher Education, 77(5), 861-885. https://doi.org/10. 1353/jhe.2006.0042

Jenkins, S. R., Belanger, A., Connally, M. L., Boals, A., \& Durón, K. M. (2013). First-generation undergraduate students' social support, depression, and life satisfaction. Journal of College Counseling, 16(2), 129-142. https://doi.org/10.1002/j.2161-1882.2013.00032.x

Jordan, S., Gessnitzer, S., \& Kauffeld, S. (2017). Develop yourself, develop others? How coaches and clients benefit from train-the-coach courses. Coaching: an International Journal of Theory, Research and Practice, 10(2), 125-139. https://doi.org/10.1080/17521882.2017.1330353

Jordan, S., \& Kauffeld, S. (2018). Laufbahnberatung für SchülerInnen und Studierende. In S. Kauffeld \& D. Spurk (Eds.), Handbuch Karriere und Laufbahnmanagement. Springer. https://doi.org/10.1007/ 978-3-662-45855-6_3-1

Klauke, F., Meinecke, A., Müller-Frommeyer, L., \& Kauffeld, S. (2019). Integrating foreigners into local communities for mutual benefit: chances, challenges, and best practice. In J. Allen \& R. ReiterPalmon (Eds.), The Cambridge handbook of organizational community engagement and outreach. Cambridge Handbooks in Psychology (pp. 92-112). Cambridge University Press. https://doi.org/10. 1017/9781108277693.006

Kogovšek, T., Ferligoj, A., Coenders, G., \& Saris, W. E. (2002). Estimating the reliability and validity of personal support measures: Full information ML estimation with planned incomplete data. Social Networks, 24(1), 1-20.

Kojaku, L. K., Nuñez, A.-M., \& Malizio, A. G. (1998). Descriptive summary of 1995-96 beginning postsecondary students: With profiles of students entering 2- and 4-year institutions. Statistical analysis report / National Center for Education Statistics. U.S. Dept. of Education, Office of Educational Research and Improvement; For sale by the U.S. G.P.O., Supt. of Docs.

Lent, R. W., Brown, S. D., \& Hackett, G. (2000). Contextual supports and barriers to career choice: A social cognitive analysis. Journal of Counseling Psychology, 47(1), 36-49. https://doi.org/10.1037// 0022-0167.47.1.36

Levine, A., \& Nidiffer, J. (1996). Beating the odds: How the poor get to college. The Jossey-Bass higher and adult education series. San Francisco: Jossey-Bass Publishers.

Lin, N. (1999). Social networks and status attainment. Annual Review of Sociology, 25(1), 467-487. https://doi.org/10.1146/annurev.soc.25.1.467

Lin, N. (2001). Social capital: A theory of social structure and action. Structural analysis in the social sciences, 19. Cambridge University Press. http://site.ebrary.com/lib/academiccompletetitles/home. action

Middendorff, E., Apolinarski, B., Poskowsky, J., \& Kandulla, M. (2012). Die wirtschaftliche und soziale Lage der Studierenden in Deutschland 2012: 20. Sozialerhebung des Deutschen Studentenwerks durchgeführt durch das HIS-Institut für Hochschulforschung. Retrieved from May 10, 2019, from https://www.studentenwerke.de/sites/default/files/01_20-SE-Hauptbericht.pdf

Moschetti, R. V., \& Hudley, C. (2015). Social capital and academic motivation among first-generation community college students. Community College Journal of Research and Practice, 39(3), 235251. https://doi.org/10.1080/10668926.2013.819304

Mounts, N. (2000). Parental management Parental management of adolescent peer relationships in context: The role of parenting style. Journal of Family Psychology, 16(1), 58-69.

O'Shea, S. (2016). Avoiding the manufacture of 'sameness': First-in-family students, cultural capital and the higher education environment. Higher Education, 72(1), 59-78. https://doi.org/10.1007/ s10734-015-9938-y

Pascarella, E. T., Pierson, C. T., Wolniak, G. C., \& Terenzini, P. T. (2004). First-generation college students: Additional evidence on college experiences and outcomes. The Journal of Higher Education, 75(3), 249-284. https://doi.org/10.1353/jhe.2004.0016

Perst, H., Thies, B., \& Uhde, G. (2019). Konzeption einer Schulung für studentische Mentorinnen und Mentoren. In G. Uhde und B. Thies (Hrsg.). Kompetenzentwicklung im Lehramtsstudium durch professionelles Training. Technische Universität Braunschweig.

Pike, G. R., \& Kuh, G. (2005). First- and second-generation college students: A comparison of their engagement and intellectual development. The Journal of Higher Education, 76(3), 276-300. https://doi.org/10.1353/jhe.2005.0021 
Portes, A. T., \& Sensenbrenner, J. (1993). Embeddedness and immigration: Notes on the social determinants of economic action. American Journal of Sociology, 98(6), 1320-1350.

Putnam, R. D. (2000). Bowling alone: The collapse and revival of American community. NewYork: Simon \& Schuster.

Raufelder, D., \& Ittel, A. (2012). Mentoring in der Schule: ein Überblick ; theoretische und praktische Implikationenfür Lehrer/-innen und Schüler/-innen im internationalen Vergleich. Diskurs Kindheitsund Jugendforschung /Discourse. Journal of Childhood and Adolescence Research, 7(2), 147-160. https://nbn-resolving.org/urn:nbn:de:0168-ssoar-389900

Redford, J., Hoyer, K. M., \& Mulvaney K. (2017). First-generation and continuing-generation college students: A comparison of high school and postsecondary experiences. Stats in Brief. NCES 2018-009

Renn, R. W., Steinbauer, R., Taylor, R., \& Detwiler, D. (2014). School-to-work transition: Mentor career support and student career planning, job search intentions, and self-defeating job search behavior. Journal of Vocational Behavior, 85(3), 422-432. https://doi.org/10.1016/j.jvb.2014.09.004

Rowold, J. (2004). Karriereplanung. Deutsche Übersetzung des Fragebogens zur Karriereplanung von Gould, 1979 [Career planning. German translation of Gould's career planning scale]. Westfälische Wilhelms-Universität.

Rubio, L., Mireles, C., Jones, Q., \& Mayse, M. (2008). Identifying issues surrounding first generation students. American Journal of Undergraduate Research, 14(1), 5-10. https://doi.org/10.33697/ajur. 2017.002

Schulz, U., \& Schwarzer, R. (2003). Soziale Unterstützung bei der Krankheitsbewältigung. Die Berliner Social Support Skalen (BSSS) [Social support in coping with illness: The Berlin Social Support Scales (BSSS)]. Diagnostica, 49, 73-82.

Soares, J. (2007). The power of privilege: Yale and America's elite colleges. Stanford University Press.

Stanton-Salazar, R., Chávez, L. F., \& Tai, R. H. (2001). The help-seeking orientations of Latino and non-Latino urban high school students: A critical-sociological investigation. Social Psychology of Education, 5(1), 49-82. https://doi.org/10.1023/A:1012708332665

Super, D. E. (1990). A life-span, life-space approach to career development. In D. Brown \& L. Brooks (Eds.), The Jossey-Bass management series and The Jossey-Bass social and behavioral science series. Career choice and development: Applying contemporary theories to practice (pp. 197-261). Jossey-Bass.

Tajfel, H., Turner, J. C., Austin, W. G., \& Worchel, S. (1979). An integrative theory of intergroup conflict. Organizational identity: A reader, 56-65.

Taveira, M. D. C., Silva, M. C., Rodriguez, M. L., \& Maia, J. (1998). Individual characteristics and career exploration in adolescence. British Journal of Guidance and Counselling, 26(1), 89-104. https:// doi.org/10.1080/03069889808253841

Terenzini, P. T., Springer, L., Yaeger, P. M., Pascarella, E. T., \& Nora, A. (1996). First-generation college students: Characteristics, experiences, and cognitive development. Research in High Education. https://doi.org/10.1007/BF01680039

Tinto, V. (1975). Dropout from higher education: A theoretical synthesis of recent research. Review of Educational Research, 45, 89-125. https://doi.org/10.3102/00346543045001089

Thomas, E., \& Quinn, J. (2007). First generation entry into higher education: An international study. Society for research into higher education. Society for Research into Higher Education and Open University Press. http://search.ebscohost.com/login.aspx?direct=trueandscope $=$ siteanddb=nlebk anddb $=$ nlabkandAN $=234255$

Toutkoushian, R., Stollberg, R., \& Slaton, K. (2018). Talking 'bout my generation: Defining “first-generation college students" in higher education research. Teachers College Record, 120, 1-38.

Vaux, A. (1985). Variations in social support associated with gender, ethnicity, and age. Journal of Social Issues, 41(1), 89-110. https://doi.org/10.1111/j.1540-4560.1985.tb01118.x

Wilcox, P., Winn, S., \& Fyvie-Gauld, M. (2005). 'It was nothing to do with the university, it was just the people': The role of social support in the first-year experience of higher education. Studies in Higher Education, 30(6), 707-722. https://doi.org/10.1080/03075070500340036

Zikic, J., \& Klehe, U.-C. (2006). Job loss as blessing in disguise: Career activities as predictors of reemployment quality. Journal of Vocational Behavior, 69, 391-409.

Publisher's Note Springer Nature remains neutral with regard to jurisdictional claims in published maps and institutional affiliations. 